\title{
STRATEGI PENGEMBANGAN USAHA INDUSTRI MIKRO PENGOLAHAN BANDENG PRESTO 27 SEMARANG
}

\author{
Siti Arbainah*, Jati Handayani, Nikmatuniayah, Muhammad Rois, \\ Lardin Korawijayanti
}

\author{
Jurusan Akuntansi, Politeknik Negeri Semarang \\ Jl. Prof. H. Soedarto, SH Tembalang Semarang 50275 \\ *E-mail: arbainah.siti@gmail.com
}

\begin{abstract}
Abstrak
Pemberdayaan UMKM saat ini mendapat perhatian khusus oleh pemerintah, termasuk pemeritah Kota Semarang. Peningkatan industri mikro ditempuh dengan peningkatan progam pemberdayaan ekonomi keluarga melalui peningkatan industri rumah tangga dari kelurahan. Di Kampung Dempel Kelurahan Muktiharjo Kidul Kecamatan Pedurungan terdapat industri rumah tangga yang memproduksi dan memasarkan bandeng presto, dengan merk dagang Bandeng Presto 27 Semarang. Usaha ini masih tergolong baru karena mulai beroperasi pada tanggal 23 Nopember 2018 yang dirintis ibu Budi Handayani (bu Yani) bersama suami. Usaha ini berpotensi untuk dikembangkan. Di samping produknya merupakan salah satu produk unggulan di kota Semarang, juga karena penjualannya semakin meningkat. Penjualan yang semula hanya dititipkan di warung sekitar saat ini sering menerima pesanan memenuhi kebutuhan orang yang punya hajatan. Jumlah produksi semula hanya $15 \mathrm{~kg}$ per minggu saat ini rata-rata menjadi $25 \mathrm{~kg}$ per minggu. Dari kondisi ini pemilik usaha berencana akan meningkatkan usahanya dengan menambah peralatan produksi, punya stok bahan mentah yang siap diolah setiap saat, memperluas pemasaran melalui online dan lain-lain. Berkenaan dengan rencana pengembangan tersebut maka sangat perlu disusun strategi pengembangan usaha bandeng presto 27 Semarang yang di dasari pemetaan factor kekuatan dan kelemahan yang dimiliki serta faktor apa yang menjadi peluang dan ancaman dalam menjalankan bisnis tersebut. Ruang lingkup pemetaan mencakup empat aspek manajemen usaha yaitu produksi/operasional, pemasaran, keuangan dan SDM. Pengumpulan data melalui wawancara mendalam kepada pemilik/pelaku usaha dengan bantuan kuesioner. Data yang terkumpul dianalisis secara kualitatif dan selajutnya didiskripsikan dengan mengacu pada item analisis SWOT guna menentukan peta kekuatan, kelemahan, peluang dan ancaman. Hasil pemetaan ini selanjutnya menjadi dasar perumusan strategi pengembangan usaha pada industri mikro pengolahan Bandeng Presto 27 Semarang. Hasil penelitian memberikan empat alternative strategi yang dapat digunakan yaitu SO-ST-WO-WT.
\end{abstract}

Kata Kunci: Industri Mikro, industri pengolahan, bandeng presto, Analisis SWOT.

\section{PENDAHULUAN}

Kota Semarang mempunyai beberapa makanan khas sebagai oleh-oleh antara lain bandeng presto. "Serasa belum ke Semarang apabila belum membawa bandeng presto", meskipun sebenarnya bandeng presto tersebut bukan merupakan makanan asli dari Semarang. Kondisi ini menyebabkan usaha bandeng presto terus berkembang. Beberapa industri rumah tangga mulai bergeliat memproduksi dan memasarkan oleh-oleh khas Semarang ini untuk memenuhi kalangan yang tidak mampu menjangkau bandung presto 
kelas atas yang dipasarkan di pusat oleh-oleh Jalan Pandanaran Semarang. Salah satu usaha skala rumah tangga yang memproduksi dan memasarkan bandeng presto ini adalah industri mikro "Bandeng Presto 27 Semarang". Industri ini beralamat lengkap di Kampung Dempel RT 02 RW16 Kelurahan Muktiharjo Kidul Kecamatan Pedurungan Kota Semarang. Produk yang dihasilkan Bandeng Presto original dan Bandeng Presto Goreng Krispi.

Bandeng Presto 27 Semarang merupakan industri mikro/industri skala rumah tangga, dirintis oleh Ibu Budi Handayani (Ibu Yani) yang lahir di Semarang pada tanggal 7 April 1974 dan mulai beroperasi pada tanggal 23 Nopember 2018. Industri mikro adalah industri dengan usaha produktif milik orang perorangan dan/atau badan usaha perorangan yang memenuhi karakteristik tertentu, salah satunya jumlah tenaga kerja 1-4 orang. (BPS, https://www.bps.go.id, 2016). Berdasarkan informasi yang diperoleh saat survey awal diketahui bahwa Bandeng Presto 27 Semarang mempunyai dua orang pekerja sekaligus pemilik. Produksi secara rutin dilakukan untuk memenuhi penjualan di warung-warung dan memproduksi berdasarkan pesanan untuk memenuhi pesanan dari orang yang mempunyai hajatan sebagai oleh-oleh/ bingkisan pulang. Dari kondisi tersebut sangat jelas dan tepat bahwa Bandeng Presto 27 Semarang ini merupakan industri mikro. Industri mikro adalah bagian dari Usaha Mikro, Kecil dan Menengah (UMKM). Banyak penelitian yang menyebutkan bahwa UMKM atau juga dapat disebut dengan Industri Mikro Kecil Menengah (IMKM) mempunyai peran yang strategis dalam pembangunan ekonomi nasional, karena selain berperan dalam pertumbuhan ekonomi dan penyerapan tenaga kerja juga berperan dalam pendistribusian hasil-hasil pembangunan. (Ulfi, Hidayat \& Budiatmo, hal 1). Pernyataan ini diperkuat dengan "UKM memiliki peran strategis dalam upaya pemerintah memerangi kemiskinan melalui penciptaan lapangan kerja” (Murtiasri, 2012). Dari dua pernyataan tersebut dapat dikatakan UMKM/IMKM mempunyai kedudukan, potensi serta peranan sangat penting dalam perekonomian untuk mewujudkan tujuan pembangunan nasional, tidak terkecuali industri mikro Bandeng Presto 27 Semarang.

Bedasarkan survey awal diketahui bahwa Ibu Yani sebagai pelaku usaha sekaligus pemilik Bandeng Presto 27 Semarang bertekad untuk meningkatkan kualitas dan kapasitas produksi maupun pemasaran. Niatan ini cukup beralasan karena dari bulan ke 
bulan produksi dan penjualannya meningkat. Namun seperti halnya permasalahan umum yang dihadapi IMKM, industri mikro Bandeng Presto 27 Semarang ini juga memiliki keterbatasan dalam aspek kompetensi sumberdaya manusia maupun sumber daya lain yang berdampak pada lemahnya daya saing. Berpijak pada kondisi tersebut maka rencana pengembangan usaha yang dicanangkan Bandeng Presto 27 Semarang perlu strategi yang tepat agar keputusan yang diambil memberikan hasil yang tepat pula. Oleh karena itu diperlukan pengkajian untuk merumuskan strategi pengembangan usaha dengan berbasis pada aspek kekuatan dan kelemahan yang dimiliki maupun aspek peluang dan ancaman yang dihadapi. Hal inilah yang melatarbelakangi penelitian dengan judul Strategi Pengembangan Usaha Industri Mikro Pengolahan Bandeng Presto 27 Semarang.

Berpijak pada judul penelitian dan permasalahan industri mikro Bandeng Presto 27 Semarang maka masalah yang dikaji dalam penelitian ini adalah bagaimana meningkatkan kemampuan usaha industri pengolahan Bandeng Presto 27 Semarang agar dapat berkembang dengan cara mengelola kekuatan dan kelemahan yang dimiliki untuk menghadapi peluang maupun ancaman usaha yang ada.. Dari hasil penelitian ini dirumuskan strategi pengembangan usaha berbasis analisis SWOT yang cocok dengan kondisi industri mikro tersebut. Adapun batasan masalah dalam penelitian ini meliputi kondisi internal (kekuatan dan kelemahan) serta kondisi eksternal (peluang dan ancaman) yang dimiliki industri mikro pengolahan Bandeng Presto 27 Semarang, dengan cakupan aspek pemasaran, produksi, keuangan dan sumber daya manusia. Penelitian ini bertujuan untuk 1) merumuskan kekuatan, kelemahan, peluang dan ancaman yang terdapat pada industri mikro pengolahan Bandeng Presto 27 Semarang. 2). Merumuskan strategi pengembangan usaha barbasis analisis SWOT bagi industri mikro pengolahan Bandeng Presto 27 Semarang.

\section{METODE PENELITIAN}

Obyek penelitian ini adalah industri mikro pengolahan Bandeng Presto 27 Semarang, Kampung Dempel RT 02 RW 16 Kelurahan Muktiharjo Kidul Pedurungan Semarang. Alamat email: bhandayani438@gmail.com. Penelitian ini termasuk penelitian studi kasus, sehingga keseluruhan aspek obyek penelitian diselidiki. Data 
yang dibutuhkan dalam penelitian ini adalah data primer. Data primer dikumpulkan menggunakan metode survey dan wawancara mendalam dengan bantuan kuesioner dengan pemilik dan pelaku usaha Bandeng Presto 27 Semarang. Hal ini digunakan untuk menggali informasi dari industri mikro berkaitan dengan permasalahan yang sedang diteliti (kondisi internal dan eksternal perusahaan). Selain itu data sekunder berasal dari BPS (Badan Pusat Statistik) atau jurnal ilmiah yang diperoleh dalam bentuk hard copy maupun diunduh dari internet.

Teknik analisis data dilakukan secara diskriptif kualitatif. Hal ini digunakan untuk mengetahui diskripsi potensi dan perkembangan Bandeng Presto 27 Semarang. Analisis kualitatif dari hasil wawancara diklasifikasi menjadi kekuatan, kelemahan (kondisi internal); peluang dan ancaman (kondisi eksternal) dari industri mikro yang meliputi aspek produksi, pemasaran, keuangan dan sumber daya manusia. Tahap selanjutnya dilakukan analisis SWOT, yaitu menganalisis faktor strategis perusahaan meliputi kekuatan, kelemahan, peluang dan ancaman dalam kondisi saat ini (Rangkuti, F, 2012). Hasil analisis SWOT selanjutnya disajikan dalam bentuk Matrik SWOT untuk menentukan/menyusun 4 (empat) alternatif strategi pengembangan usaha. Hampir setiap perusahaan maupun pengamat bisnis menggunakan pendekatan analisis SWOT untuk menentukan kebijakan yang dilakukan. Kecenderungan ini tampaknya akan terus meningkat, terutama dalam era perdagangan bebas abad 21, yang satu sama lain saling berhubungan dan saling bergantung. (Sugiarti, 2015:4). Uraian teknik analisis data dalam penelitian ini dapat dijelaskan dalam Kerangka Kerja Penelitian pada Gambar 1.

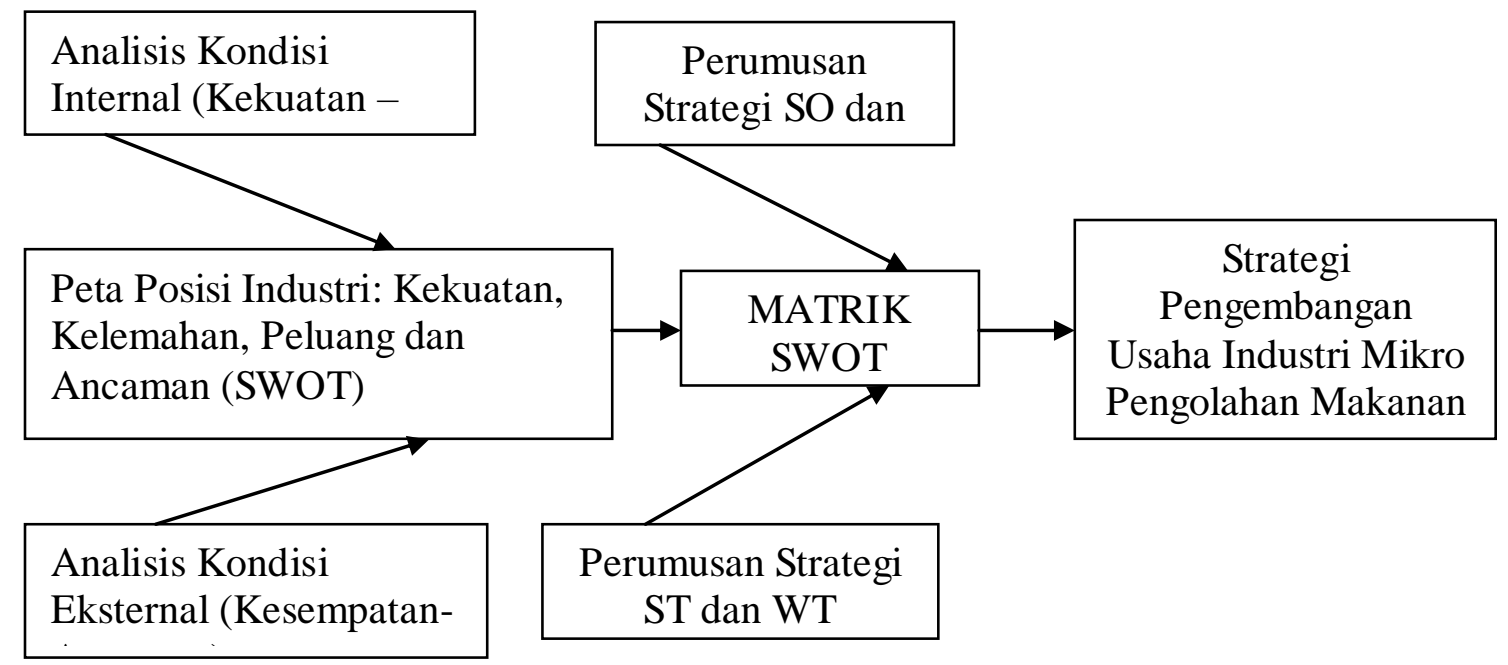


Gambar 1. Kerangka Kerja Penelitian dalam bentuk Fishbone Diagram

\section{HASIL DAN PEMBAHASAN}

Industri mikro Bandeng Presto 27 Semarang termasuk industri mikro yang masih muda, baru berusia dua tahun, karena mulai beroperasi 23 Nopember 2018. Berdasarkan hasil wawancara dengan pelaku usaha sekaligus sebagai pemilik yaitu Ibu Budi Handayani diketahui bahwa Bandeng Presto 27 memproduksi dan menjual sebanyak kurang lebih $20 \mathrm{Kg}$ bandeng/minggu. Meskipun masih baru namun pemilik menyatakan kondisi usaha mengalami kenaikan. Permasalahan utama yang dihadapi saat ini adalah harga bahan baku yang tidak stabil (naik turun) sehingga menyulitkan dalam penentuan harga jual. Permasalahan lain yang dihadapi saat ini adalah persaingan harga dengan competitor. Namun demikian dalam jangka panjang Bandeng presto 27 Semarang ini memiliki peran yang strategis dalam Upaya Peningkatan Pendapatan Keluarga (UP2K) sekaligus dapat menunjang wisata kuliner oleh-oleh khas Semarang. Bandeng Presto 27 Semarang sangat layak untuk dikembangkan. Hal ini sejalan dengan kondisi Semarang dan Jawa Tengah pada uumnya. Menurut Kepala Dinas Koperasi dan UKM Provinsi Jawa Tengah, Ema Rachmawati saat ini UMKM memang tengah menggeliat. Peningkatannya terhitung cepat. Data terbaru, jumlah UMKM di Jawa Tengah 4.174.210 unit. Dari jumlah itu, untuk usaha besar 3.358 unit, usaha menengah 39.125 unit, usaha kecil 354.884 unit, dan usaha mikro 3.776.843 unit. Sementara berdasarkan data sensus ekonomi nasional BPS tahun 2016 tercatat ada ratusan ribu unit UMKM binaan provinsi. Yaitu 159.308 unit. (Edi Suwiknyo - Bisnis.com 18 Januari 2020)

Pengembangan usaha dapat dilakukan dengan tepat apabila perusahaan mampu memanfaatkan kekuatan untuk mengurangi kelamahan dan memanfaatkan peluang untuk menanggulangi ancaman. Dari lima aspek yang diteliti dan ditanyakan langsung kepada pemilik usaha tentang urutan skala prioritas aspek tersebut dalam menunjang/ mendukung kesuksesan usaha maka dinyatakan urutan yang sangat berperan ke yang kurang berperang adalah 1) aspek pemasaran; 2) sumber daya manusia; 3) Keuangan; 4) Teknologi; 5)Struktur organisasi/ susunan organisasi. Hasil rangkuman persepsi pemilik/pelaku tentang kondisi industri yang ditinjau dalam empat aspek manajemen 
mengenai permasalahan yang dihadapi berikut cara mengatasi permasalahan yang telah dilakukan maupun akan dilakukan disajikan dalam Tabel 1 berikut ini.

Tabel 1. Persepsi Pemilik Usaha Tentang Aspek Manajemen Usaha pada Industri Mikro Bandeng Presto 27 Semarang

\begin{tabular}{|c|c|c|c|}
\hline No & $\begin{array}{l}\text { Aspek Yang } \\
\text { Diteliti }\end{array}$ & Permasalahan & $\begin{array}{c}\text { Cara Mengatasi yang sudah } \\
\text { dilakukan dan yang } \\
\text { direncanakan }\end{array}$ \\
\hline 1 & $\begin{array}{l}\text { Aspek } \\
\text { Pemasaran }\end{array}$ & $\begin{array}{l}\text { Pembeli/Reseler sering } \\
\text { meminta harga yang murah. } \\
\text { Pemasaran masih terbatas } \\
\text { Promosi melalui media } \\
\text { online, tetapi belum } \\
\text { mempunyai Web. }\end{array}$ & $\begin{array}{l}\text { Meyakinkan konsumen dengan } \\
\text { menjaga kualitas produk. } \\
\text { Pemasaran yang sudah dilakukan: } \\
\text { buka layanan order online; } \\
\text { dititipkan di tukang sayur yang } \\
\text { punya lapak. } \\
\text { Ingin melakukan ekspansi } \\
\text { pemasaran usaha ke luar kota. }\end{array}$ \\
\hline 2 & SDM & $\begin{array}{l}\text { Tenaga kerja freeline } \\
\text { kadang sulit diperoleh }\end{array}$ & Pakai tenaga saudara, tetangga. \\
\hline 3 & Keuangan & Tidak ada kendala & $\begin{array}{l}\text { Menggunakan tabungan dari Gaji } \\
\text { suami. }\end{array}$ \\
\hline 4 & Produksi & $\begin{array}{l}\text { Harga bahan baku tidak } \\
\text { stabil }\end{array}$ & $\begin{array}{l}\text { Mencari supliyer bahan baku. } \\
\text { Keunggulan produk rasa dan } \\
\text { kemasan }\end{array}$ \\
\hline
\end{tabular}

Sumber: Data Primer yang diolah

Kecuali berdasarkan pendapat pemilik/pelaku usaha khusus untuk rasa dari produk bandeng presto 27 Semarang tersebut telah dilakukan testimoni terhadap 10 orang yang diberi produk dan diminta memberikan penilaian tentang rasa dan kemasan. Dari 10 orang tersebut 9 dari mereka menyatakan enak. Bahkan ada yang menyatakan gurih dan tidak kalah dengan bandeng presto lainnya yang harga lebih mahal. Dari Kemasan ada yang memberi masukan untuk diperbaiki tampilannya agar lebih menarik bila akan dijadikan oleh oleh.

Setelah menginvetarisir data kekuatan, kelemahan, peluang dan ancaman dapat disusunlah matrik SWOT. Pada Matrik tersebut terdapat empat alternative strategi yang dapat dikembangkan (Alfi, hidayat dan Budiatma, hal 6) yaitu: 
1. Strategi SO (Strengths-Opportunities)- Memanfaatkan kekuatan untuk meraih peluang yang tersedia.

2. Strategi WO (Weakness-Opportunities)- Mengatasi kelemahan untuk meraih peluang yang tersedia

3. Strategi ST (Strengths-Threats) - Menggunakan kekuatan untuk mengantisipasi/mengatasi adanya ancaman.

4. Strategi WT(Weakness-Threats) adalah strategi dengan meminimalkan/mengurangi kelemahan untuk menghindari ancaman.

Mengacu pada pijakan teori tersebut dan berpijak pada kondisi indusri mikro Bandeng Presto 27 Semarang maka dapat dirumuskan ke empat alternative strategi yang dapat dipilih oleh Bandeng presto 27. Dalam matrik tersebut sudah dijabarkan bentukbentuk strategi seperti apa yang dapat dilaksanakan apakah SO-WO-ST-WT. Sebagai contoh jika industri mikro ingin memilih memanfaatkan kekuatan untuk meraih peluang yang tersedia maka alternative SO yang diterapkan. Dalam usaha Bandeng presto 27 ini antara lain adalah dapat ditempuh dengan mempertahankan kualitas rasa produk untuk meraih peluang pasar yang tersedia. Jika ingin memperbaiki kelemahan untuk meraih peluang yang ada maka alternative WO yang diterapkan. Bentuk riil alternative tersebut antara lain yaitu dengan menempuh cara memperbaiki kualitas kemasan produk agar layak dan tahan lama sebagai makanan khas oleh-oleh Semarang. Begitu seterusnya dapat dipilih strategi mana yang akan diterapkan masih ada dua strategi lagi yaitu ST ataupun WT. Secara lengkap matrik SWOT bandeng Presto 27 tertuang dalam Gambar 2 .

\begin{tabular}{|c|c|c|}
\hline Internal & $\begin{array}{l}\text { Kekuatan } \\
\text { (Strengths) }\end{array}$ & Kelemahan (Weaknesses) \\
\hline Eksternal & $\begin{array}{l}\text { 1. Rasa produk enak,gurih } \\
\text { dan khas } \\
\text { 2. Harga relative murah } \\
\text { 3. Ada varian rasa (original } \\
\text { dan goreng) } \\
\text { 4. Penjualan cenderung } \\
\text { meningkat }\end{array}$ & $\begin{array}{l}\text { 1. Kapasitas Produksi } \\
\text { Kecil } \\
\text { 2. Kemasan masih } \\
\text { sederhana } \\
\text { 3. SDM blm pengalaman } \\
\text { 4. Peralatan terbatas } \\
\text { 5. Manajemen usaha } \\
\text { belum tertata }\end{array}$ \\
\hline
\end{tabular}




\begin{tabular}{|c|c|c|}
\hline Peluang (Opportunities) & SO STRATEGY & WO STRATEC \\
\hline $\begin{array}{l}\text { 1. Peluang pasar masih } \\
\text { tersedia } \\
\text { 2. Sebagai ciri oleh-oleh } \\
\text { makanan khas } \\
\text { Semarang } \\
\text { 3. Perkembangan } \\
\text { teknologi untuk } \\
\text { industri yang semakin } \\
\text { maju }\end{array}$ & $\begin{array}{l}\text { Mempertahankan kualitas } \\
\text { rasa produk untuk meraih } \\
\text { peluang pasar yang tersedia }\end{array}$ & $\begin{array}{l}\text { Memperbaiki kualitas } \\
\text { kemasan produk agar layak } \\
\text { dan tahan lama sebagai } \\
\text { makanan khas oleh-oleh } \\
\text { Semarang. } \\
\text { Menambah } \\
\text { meningkatkan peralatan } \\
\text { agar dapat memanfaatkan } \\
\text { peluang pasar yang } \\
\text { tersedia. }\end{array}$ \\
\hline $\begin{array}{l}\text { 1. Persaingan harga } \\
\text { dengan competitor } \\
\text { 2. Harga bahan baku } \\
\text { cenderung naik } \\
\text { 3. Perkembangan } \\
\text { teknologi sangat } \\
\text { cepat }\end{array}$ & $\begin{array}{l}\text { Mempertahankan } \\
\text { keunggulan harga untuk } \\
\text { memenangkan persaingan, } \\
\text { dengan mengendalikan biaya } \\
\text { produksi misal mencari } \\
\text { supplier bahan baku dengan } \\
\text { harga yang cocok }\end{array}$ & $\begin{array}{l}\text { Meningkatkan kemampuan } \\
\text { SDM dan } \\
\text { mengimplementasikan } \\
\text { manajemen usaha yang } \\
\text { baik agar dapat mengikuti } \\
\text { perkembangan teknologi } \\
\text { industri dan memenangkan } \\
\text { persaingan }\end{array}$ \\
\hline
\end{tabular}

Gambar 2. Matrik SWOT Industri Mikro Bandeng Presto 27 Semarang

Melihat pada matrik SWOT pada Gambar 2 dapat diketahui aspek internal industri mikro Bandeng presto 27 Semarang dari sisi kekuatan dan kelemahan, dan aspek ekternal yaitu adanya peluang dan ancaman. Matriks kekuatan-Kelemahan-KesempatanAncaman (Strengths-Weaknesses-Opportunities-Threats-SWOT) adalah alat pencocokan penting yang membantu manajer mengembangkan empat tipe strategi yaitu strategi kekuatan -kesempatan; strategi kelemahan -kesempatan; strategi kekuatanancaman dan strategi kelemahan -ancaman. (David, 2016: 171). Jika melihat matrik SWOT yang sudah disusun bahwa kekuatan dan kelemahan industri mikro bandeng presto jumlahnya seimbang, demikian pula di bagian kesempatan dan ancaman juga seimbang. Hal ini dapat diartikan bahwa posisi industri mikro bandeng presto dalam kondisi rata-rata. Kemungkinaannya untuk berkembang masih terbuka cukup. Artinya dapat memilih alternative mana yang akan diterapkan. Berbeda apabila kekuatan sangat banyak peluang banyak tetapi kelemahan kecil maka dapat diartikan kemungkinan posisi industri berada di atas rata-rata, ini akan lebih cepat apabila memanfaatkan 
strategi kekuatan-peluang atau kekuatan-ancaman dan seterusnya. Pemilihan strategi sangat tergantung kepada manajer, kerna pengambilan keputusan sang manajer itu adalah seni meskipun dapat disandarkan pada ilmu juga. Demikian pula pada hasil penelitian ini, akan diserahkan kepada pemilik usaha industri mikro Bandeng Presto 27 Semarang.

\section{SIMPULAN}

Berdasarkan uraian dalam pembahasan dan mengacu pada tujuan yang telah ditetapkan maka dapat disimpulkan bahwa industri mikro Bandeng Presto 27 Semarang memiliki aspek kekuatan, kelemahan; peluang dan ancaman sebagai berikut:

1. Kekuatan yang dimiliki adalah rasa produk enak,gurih dan khas; harga relative murah, ada varian rasa (original dan goreng); Penjualan cenderung meningkat .

2. Kelemahan yang ada yaitu: Kapasitas Produksi Kecil; Kemasan masih sederhana, SDM blm pengalaman; Peralatan terbatas; Manajemen usaha belum tertata.

3. 3. Peluang (Opportunities): Peluang pasar masih tersedia, Sebagai ciri oleholeh makanan khas Semarang; Perkembangan teknologi untuk industri yang semakin maju.

4. Ancaman (Threats): Persaingan harga dengan competitor; Harga bahan baku cenderung naik; Perkembangan teknologi sangat cepat

Dari kondisi kekuatan-kelemahan-kesempatan-ancaman dikembangkan matriks SWOT yang menggambarkan empat alternatif strategi bisnis yang dapat dipilih yaitu SO-WO-ST-WT. Jabaran isi alternative strategi tersebut telah disesuaikan dengan kondisi industri mikro bandeng presto 27 Semarang.

\section{DAFTAR PUSTAKA}

Amalia, alfi, Wahyu Hidayat, Agung Budiatmo, Analisis Strategi Pengembangan Usaha Pada UKM Batik Semarangan di Kota Semarang, Jurnal Ilmu Administrasi Bisnis, Universitas Diponegoro, Semarang. Arbainah, Siti. 2020, Strategi Pengembangan Usaha Industri Mikro Pengolahan Bandeng Presto 27 Semarang, Laporan Hasil Penelitian Terapan Pratama, P3M Polines, Semarang. 
David, Fred R dan David, Forest R. 2016, Manajemen Strategik Suatu Pendekatan Keunggulan Bersaing, Penerbit Salemba 4, Jakarta.

Murtiasri, Eka, 2012, Kontribusi Usaha Kecil dan Menengah Dalam Penyerapan Tenaga Kerja Berdasar Perhitungan Concentration Index di Kabupaten Semarang, TEKNIS vol 7 No.1 April 2012, hal 50-57, Semarang.

Rangkuti, Freddy, 2005, Analisis SWOT Teknik Membedah Kasus Bisnis, PT Gramedia Pustaka Utama, Jakarta.

Sugiarti, 2015, Strategi Pengembangan Potensi Unggulan Daerah Pada UMKM Komoditi Sarung Goyor Di Kabupaten Sragen, Laporan Hasil Penelitian Terapan, P3M Polines, Semarang.

Suwignyo, 2020, Kunci Penurunan Kemiskinan Jawa Tengah Ada di UMKM, Ini

Penjelasannya. Bisnis.com, 18 Januari 2020. (diunduh 20 Maret)

UU RI No. 20 Tahun 2008, Tentang Usaha Mikro, Kecil dan Menengah. 